\title{
In vivo antimicrobial efficacy of $6 \%$ Morinda citrifolia, Azadirachta indica, and 3\% sodium hypochlorite as root canal irrigants
}

\author{
Rajesh Podar ${ }^{1}$, Gaurav P. Kulkarni ${ }^{1}$, Shifali S. Dadu ${ }^{1}$, Shraddha Singh ${ }^{1}$, Shishir H. Singh ${ }^{1}$
}

Correspondence: Dr. Shishir H. Singh

Email: drshishirs@hotmail.com
'Department of Conservative Dentistry and Endodontics, Terna Dental College, Nerul, Navi Mumbai, Maharashtra, India

\section{ABSTRACT}

Objective: To evaluate and compare the antimicrobial efficacy of 6\% Morinda citrifolia, Azadirachta indica, and 3\% sodium hypochlorite $(\mathrm{NaOCl})$ as root canal irrigants. Materials and Methods: Thirty nonvital maxillary anteriors were randomly assigned to one of the three groups corresponding to the irrigant to be tested; $6 \%$ Morinda citrifolia juice (MCJ) $(n=10)$, A. indica $(n=10)$ and $3 \% \mathrm{NaOCl}(n=10)$. After the root canal access opening a root canal culture sample was taken with two paper points and cultured under aerobic and anaerobic conditions. Cleaning and shaping were completed with irrigation by $10 \mathrm{~mL}$ of respective irrigants and $5 \mathrm{~mL}$ of final rinse. The patients were recalled after 3 days and canals were rinsed again with $5 \mathrm{~mL}$ of the test irrigants. This was followed by obtaining a posttreatment root canal culture sample and culturing and analyzed by counting the colony forming units (CFUs). Results: Six percentage MCJ, $A$. indica, and 3\% $\mathrm{NaOCl}$ showed a significant reduction $(P<0.05)$ in the mean CFU counts for aerobic and anaerobic bacteria between baseline and 3 days. Conclusion: There was no difference in the antimicrobial efficacy of $6 \% \mathrm{M}$. citrifolia, A. indica, and $3 \% \mathrm{NaOCl}$ as root canal irrigants.

Key words: Azadirachta indica, herbal, Morinda citrifolia, root canal irrigants, sodium hypochlorite

\section{INTRODUCTION}

The main objective of root canal treatment is complete elimination of microorganisms from the infected root canals. Although cleaning and shaping reduce microorganisms, the use of irrigants is complimentary to instrumentation in facilitating their removal. Several chemicals and therapeutic agents are used to achieve this goal. The gold standard and the most effective among these is sodium hypochlorite $(\mathrm{NaOCl}) \cdot{ }^{[1]}$ However, owing to the potential side effects, constant increase in antibiotic resistant strains, ${ }^{[2,3]}$ safety concerns, ${ }^{[4,5]}$ and cytotoxic reactions of synthetic irrigants, ${ }^{[6]}$ usage of various herbal agents has increased over the last few decades, ${ }^{[7,8]}$ and the search is on for a root canal irrigant that can match or better the gold standard. Herbal products have been used, since ancient times in dental and medical practice, and the trend is growing now due to their high antimicrobial activity, excellent biocompatibility, anti-inflammatory, and antioxidant properties. ${ }^{[9]}$
Morinda citrifolia juice (MCJ) appears to be the first juice to be identified as a possible alternative to the use of $\mathrm{NaOCl}$. Commercially, called as Noni, it is also known as Nono, Nonu, great morinda, Indian mulberry, Ba Ti Tian, dog dumpling (Barbados), mengkudu (Malaysia and Indonesia), Kumudu (Balinese), pace (Javanese), beach mulberry, Nhan, cheese fruit, and nunaakai (Tamil Nadu, India) across various cultures throughout the world. $[3,5,8,10]$ It contains antibacterial compounds L-asperuloside with alizarin ${ }^{[11]}$ and also exhibits, antiviral, antifungal,

This is an open access article distributed under the terms of the Creative Commons Attribution-NonCommercial-ShareAlike 3.0 License, which allows others to remix, tweak, and build upon the work non-commercially, as long as the author is credited and the new creations are licensed under the identical terms.

For reprints contact: reprints@medknow.com

How to cite this article: Podar R, Kulkarni GP, Dadu SS, Singh S, Singh SH. In vivo antimicrobial efficacy of $6 \%$ Morinda citrifolia, Azadirachta indica, and $3 \%$ sodium hypochlorite as root canal irrigants. Eur J Dent 2015;9:529-34.

DOI: $10.4103 / 1305-7456.172615$ 
antihelminthic, antitumor, ${ }^{[12]}$ anti-inflammatory, analgesic, hypotensive, ${ }^{[11]}$ and immune-enhancing effect, ${ }^{[13]}$ suggesting its potential to be used as an endodontic irrigant.

Azadirachta indica (neem) is known for its Indian medicinal value. Several parts of the plant such as fruits, seeds, leaves, and bark are used to isolate more than 140 compounds. The isoprenoid group of neem leaf and its constituents have demonstrated anti-inflammatory, ${ }^{[14,15]}$ immune-modulatory, ${ }^{[16]}$ antibacterial, ${ }^{[17,18]}$ antifungal, ${ }^{[18-20]}$ antiviral, antioxidant, and anti-carcinogenic properties. ${ }^{[21]}$ Although initial scientific reports have demonstrated favorable in vitro results, there is no in vivo study that has compared the antibacterial efficacy of these three root canal irrigants against aerobic and anaerobic bacteria.

The aim of the present in vivo study, therefore, was to evaluate and compare the antimicrobial efficacy of $6 \%$ $\mathrm{MCJ}, A$. indica, and $3 \% \mathrm{NaOCl}$ as root canal irrigants. The null hypothesis to be tested was that there was a difference in the antimicrobial efficacy of $6 \% \mathrm{MCJ}$, A. indica, and $3 \% \mathrm{NaOCl}$ as root canal irrigants.

\section{MATERIALS AND METHODS}

This prospective study was carried out over a period of 6 weeks. A set protocol with informed consent from the patient and ethical committee approval by Institutional Review Board - Ethics Committee of Terna Dental College and Hospital for the procedure was followed strictly. A total of 32 mature permanent maxillary central incisors, lateral incisors and canines with pulp necrosis, and asymptomatic apical periodontitis were included in the study, whereas those with calcified pulp chamber, periapical cyst, and contributory medical history were excluded from this study. The teeth were analyzed by preoperative radiographs and electric pulp test for identification of their pulpal and periapical status. Diagnosis of periapical cyst was done on intraoral periapical radiographs. Teeth having well-defined large periapical radiolucency with corticated border suggestive of a radicular cyst were excluded from the study. Antibiotics were not prescribed before or during the course of treatment. Thirty teeth were randomly assigned to 1 of the 3 groups corresponding to the irrigant to be tested; $6 \% \mathrm{MCJ}$ $(n=10)$, A. indica $(n=10)$, and $3 \% \mathrm{NaOCl}(n=10)$. The remaining two teeth served as control and were irrigated with normal saline. The clinical procedures in all the teeth were carried out by a single operator.

\section{Preparation of access cavity}

After administering local anesthesia with lignocaine containing 1:80000 adrenaline (Lignox, Warren, Mumbai, India) the tooth was polished with pumice and isolated with rubber dam. Surfaces of the tooth, rubber dam, and clamp were cleaned with $30 \%$ hydrogen peroxide followed by swabbing with $5 \%$ iodine tincture as described by Moller. ${ }^{[22]}$ An autoclaved high speed air turbine with a round diamond point (BR 40: Mani, Inc., Tochigi, Japan) was used to initiate root canal access opening. The operating area was again swabbed with $5 \%$ iodine tincture and then a low-speed engine without water coolant was used to gain final access. The cavity walls were modified using safe end cutting diamond point (EX 24: Mani, Inc., Tochigi, Japan). The root canal was accessed with size 10 K-file (Mani, Inc., Tochigi, Japan) and the contents were debrided from the canal walls by push pull motion. Sterile water was then deposited in the canal and agitated using size 10 K-file (Mani, Inc., Tochigi, Japan).

\section{Method for collection of sample}

Under aseptic conditions, initial pretreatment root canal culture sample was taken with sterile paper points. Two paper points were placed in the canal for $60 \mathrm{~s}$ and then transferred into two separate tubes of $2 \mathrm{~mL}$ brain heart infusion broth (BHI broth); each marked as aerobic and anaerobic sample. These were designated as sample no. 1 . The tubes were transferred in $10 \mathrm{~min}$ for culturing under aerobic and anaerobic conditions. After the first sample, working length was determined using electronic apex locator and confirmed by radiograph. Cleaning and shaping were done by step back technique with traditional stainless steel 0.02 taper K-files (Mani, Inc., Tochigi, Japan). Master apical size was kept three sizes larger than the initial binding instrument and a $1 \mathrm{~mm}$ step back was done until a file size that would no longer bind tightly in the canal. A total of $10 \mathrm{~mL}$ of solution of the respective test group, namely $6 \% \mathrm{MCJ}$ (Lilvera, Noni juice, Shivral Foods, India), A. indica (GMP Krishna, India), 3\% NaOCl (Prime Dental Products, Mumbai, India), and saline were used during instrumentation of the canals. After the root canal preparation was complete $5 \mathrm{~mL}$ of the respective irrigant was used as a final rinse. A sterile disposable 27 gauge needle with a beveled tip was used for all irrigation procedures and the needle was kept $1 \mathrm{~mm}$ short of the working length. The canals were dried and the access cavity was sealed with Cavit ${ }^{\mathrm{TM}} \mathrm{G}$ (3M ESPE AG, Germany). The patient was recalled after 3 days for obtaining post 
irrigation sample. After application and disinfection of the rubber dam the canals were accessed again and rinsed by $5 \mathrm{~mL}$ of the respective test solutions. In the $\mathrm{NaOCl}$ group, the canal was flushed with $5 \mathrm{~mL}$ of $5 \%$ sodium thiosulfate to neutralize the effect of $\mathrm{NaOCl}$. The canals were dried with paper points and sterile water was deposited in the canal to obtain a sample no. 2 as described earlier.

After the second sample collection, the teeth were treated using standard operating protocol with a week of calcium hydroxide intracanal medicament followed by obturation using the lateral compaction technique with gutta-percha (Dentsply Maillefer, Ballaigues, Switzerland) and zinc oxide eugenol (DPI, Mumbai, Maharashtra, India) as sealer. The final restoration was done with composite resin Tetric N-Ceram (Ivoclar Vivadent, Schaan, Liechtenstein).

\section{Microbial analysis}

The samples were subjected to microbiological analysis to ascertain their individual microbiological load. This was analyzed by counting the colony forming units (CFUs).

\section{Aerobic culturing technique}

The paper points were transferred immediately to the sterile test tubes. Within 10 minutes, the BHI broth was transferred to the microbiological lab. Ten microliters of the BHI broth were inoculated using micropipette on 5\% Columbia sheep blood agar plates (HiMedia Laboratories Pvt. Ltd., Mumbai, India). The inoculation loop was heated on the blue flame of Bunsen burner, till it became red hot. The loop was allowed to cool at room temperature and streaking was done on the agar plates. ${ }^{[23]}$ The agar plates were placed in the incubator at $37^{\circ} \mathrm{C}$ for $24 \mathrm{~h}$. After $24 \mathrm{~h}$, the bacterial growth was counted as CFUs using manual counting technique.

\section{Anaerobic culturing technique}

The lids of the test tubes were opened slightly, and paper points were inserted immediately in the BHI broth. This was done to maintain the anaerobic environment. Within 10 minutes, the BHI broth was transferred to microbiological lab. Ten microliters of BHI broth were inoculated using micropipette on $5 \%$ Columbia sheep blood agar plates (HiMedia Laboratories Pvt. Ltd., Mumbai, India). The inoculation loop was heated on the blue flame of Bunsen burner and then allowed to cool down up to room temperature before streaking was done on the agar plates. The culture plates were placed in the anaerobox chamber with its accessories (anaerogas pouch and anaerogas indicator tablet) and then incubated for $24 \mathrm{~h}$ at $37^{\circ} \mathrm{C}$. Anaerogas pouch and indicator tablet maintained anaerobic environment in anaerobox. ${ }^{[24]}$

After $24 \mathrm{~h}$, the bacterial growth was counted as CFUs using the manual counting technique. Microbial counting was done for both aerobic and anaerobic culture in the form of CFUs. The data were analyzed using SPSS version 17 software (SPSS Inc, Chicago, IL, USA). Kruskal-Wallis test was performed to check for statistical significance.

\section{RESULTS}

Mean CFU counts for aerobic and anaerobic bacteria preoperatively and after a 3 day recall visit following irrigation by MCJ, A. indica, and $\mathrm{NaOCl}$ are summarized in Table 1 and Figure 1. Mean and percentage change between baseline and 3 day recall CFU counts for aerobic and anaerobic bacteria following irrigation by MCJ, $A$. indica, and $\mathrm{NaOCl}$ are summarized in Table 2. MCJ, Neem, and $\mathrm{NaOCl}$ showed significant reduction $(P<0.05)$ in the mean CFU counts for aerobic and anaerobic bacteria

\begin{tabular}{|c|c|c|}
\hline & $n$ & Mean (SD) \\
\hline \multicolumn{3}{|c|}{ Preaerobic } \\
\hline MCJ & 10 & $59.0(49.25)$ \\
\hline Neem & 10 & $74.0(48.24)$ \\
\hline $\mathrm{NaOCl}$ & 10 & $105.8(26.74)$ \\
\hline Control & 2 & $128.00(8.48)$ \\
\hline Total & 32 & $82.63(45.82)$ \\
\hline \multicolumn{3}{|c|}{ Preanaerobic } \\
\hline MCJ & 10 & 58.90 (42.99) \\
\hline Neem & 10 & $62.40(27.49)$ \\
\hline $\mathrm{NaOCl}$ & 10 & $84.70(54.77)$ \\
\hline Control & 2 & $86.00(16.97)$ \\
\hline Total & 32 & $69.75(42.19)$ \\
\hline \multicolumn{3}{|c|}{ Postaerobic } \\
\hline MCJ & 10 & $18.60(25.34)$ \\
\hline Neem & 10 & $43.00(42.87)$ \\
\hline $\mathrm{NaOCl}$ & 10 & $81.60(25.50)$ \\
\hline Control & 2 & $124.50(7.77)$ \\
\hline Total & 32 & $52.53(43.80)$ \\
\hline \multicolumn{3}{|c|}{ Postanaerobic } \\
\hline MCJ & 10 & $14.00(19.50)$ \\
\hline Neem & 10 & $24.20(17.89)$ \\
\hline $\mathrm{NaOCl}$ & 10 & $57.30(35.92)$ \\
\hline Control & 2 & $82.00(16.97)$ \\
\hline Total & 32 & 34.97 (32.71) \\
\hline
\end{tabular}


between baseline and 3 days. Intergroup comparison for the percentage reduction in aerobic and anaerobic bacteria was statistically insignificant $(P>0.05)$. There was no difference in the antimicrobial efficacy of $\mathrm{MCJ}, A$. indica, and $\mathrm{NaOCl}$ for aerobic, as well as anaerobic bacteria. When compared with the control group MCJ showed a significant reduction of aerobic and anaerobic bacteria $(P<0.05)$, while neem showed a significant reduction of anaerobic bacteria $(P<0.05)$, and $\mathrm{NaOCl}$ showed a significant reduction of only aerobic bacteria $(P<0.05)$.

\section{DISCUSSION}

Hitherto several animal and human studies have been done to study toxicity, ${ }^{[25,26]}$ cell-mediated immunity, ${ }^{[27]}$ and effectiveness of topical preparations ${ }^{[28]}$ of M. citrifolia in its different forms. Similar animal and human investigations to study the antimicrobial efficacy, ${ }^{[29,30]}$ toxicity, ${ }^{[31-33]}$ and antisecretory property ${ }^{[2,34,35]}$ of neem have been published in literature. Hence, this in vivo investigation to study the antimicrobial efficacy of herbal irrigants in an endodontic model was planned. Maxillary central incisors, lateral incisors, and canines were chosen for this study as they have a single large, wide, and straight canal in which disinfection protocol can be

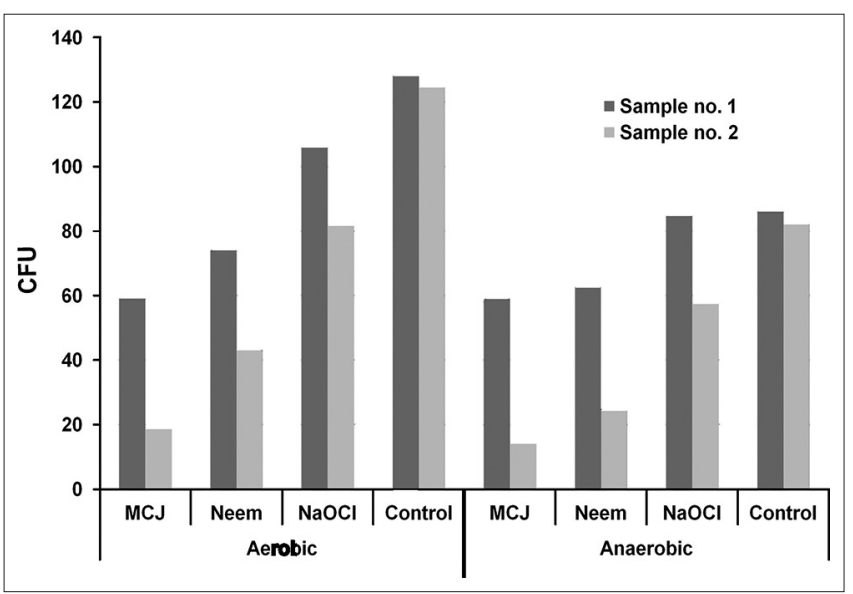

Figure 1: Reduction in mean (standard deviation) colony forming units for aerobic and anaerobic bacteria between sample no. 1 and sample no. 2 for various irrigants evaluated without procedural errors. Smith et al. ${ }^{[36]}$ have reported that for achieving comparable results and to avoid bacterial contamination from other canals in multirooted teeth and uniradicular teeth must be selected. Rubber dam isolation during endodontic treatment provides protection against salivary contamination of the pulp chamber ${ }^{[37]}$ In the present study, iodine tincture was used for decontamination of surfaces before and after initial access cavity preparation with a high speed air turbine. ${ }^{[22]}$ This was done to disinfect the tooth, rubber dam, and retainer from contamination by water spray of air turbine.

BHI broth was used as a transport medium as it propagates the growth of fastidious pathogenic cocci and other organisms. This contaminated broth was inoculated on $5 \%$ Columbia sheep's blood agar culture plates as it contains peptone which supports rapid and luxuriant growth of fastidious and nonfastidious organisms. These culture plates were used for growth of both aerobic and anaerobic microorganisms, as plates can be incubated in an atmosphere containing approximately $3-10 \%$ CO2. In the present study, anaerobic conditions were maintained by placing the agar plates in an anaerobox, a transparent polycarbonate box which contains anaerobic gas pack for consuming the residual oxygen. Simultaneously, an anaerobic indicator tablet was placed keeping the transparent cover intact and the box was sealed with a lid. This box was incubated at $37^{\circ} \mathrm{C}$ for $24 \mathrm{~h}$. The color of anaerobic indicator tablet changed to pink indicating anaerobic conditions and no leakage in the system. Microbiological research techniques often rely on accurate determination of colony forming units. This is routinely done by aliquoting a small amount of broth on culture plates. After incubation the colonies are counted to determine the number of CFUs. This is done by manual counting of colonies on plates illuminated by transmitted light. The concentration of bacteria in the original culture can then be calculated based on the assumption that each colony has raised from one single bacterium. ${ }^{[38]}$ In the current study, manual counting technique was used for determination of CFUs.

\begin{tabular}{|c|c|c|c|c|c|c|}
\hline $\begin{array}{l}\text { Name of } \\
\text { group }\end{array}$ & $\begin{array}{l}\text { Mean change } \\
\text { (aerobic) }\end{array}$ & $\begin{array}{c}\text { Percentage } \\
\text { change (aerobic) }\end{array}$ & $\begin{array}{l}\text { Mean change } \\
\text { (anaerobic) }\end{array}$ & $\begin{array}{c}\text { Percentage } \\
\text { change (anaerobic) }\end{array}$ & $\begin{array}{l}\text { Mean change } \\
\text { (total) }\end{array}$ & $\begin{array}{l}\text { Percentage } \\
\text { change (total) }\end{array}$ \\
\hline MCJ & $40.4^{*}$ & 68.47 & $44.9^{*}$ & 76.23 & 85.3 & 72.34 \\
\hline Neem & $31^{*}$ & 41.8 & $38.2^{*}$ & 61.21 & 69.2 & 51.50 \\
\hline $\mathrm{NaOCl}$ & $24.2^{*}$ & 23.04 & $27.4^{*}$ & 32.34 & 51.6 & 27.69 \\
\hline Control & 3.5 & 2.70 & 4 & 4.60 & 7.5 & 3.65 \\
\hline
\end{tabular}


Satisfactory antimicrobial efficacy of $\mathrm{NaOCl}$ as a root canal irrigant has been shown at concentrations of $3 \%{ }^{[39-41]}$ or even lower. ${ }^{[42,43]}$ Therefore, a $3 \%$ concentration was chosen for comparison. The in vivo antimicrobial efficacy of neem against a mixed flora of aerobic and facultative endodontic pathogens of primary endodontic disease was tested in the present study. Several in vitro investigations in the past have illustrated that $A$. indica can be used as a root canal irrigant owing to its desirable antimicrobial property. ${ }^{[7,44-47]}$ Agar diffusion method to study antimicrobial efficacy of neem implies that it has significant antimicrobial activity against endodontic pathogens. ${ }^{[7,45,46]}$ Tyagi et al. ${ }^{[44]}$ have found neem to have a lower antimicrobial efficacy than $5 \% \mathrm{NaOCl}$ against $C$. Albicans. Although we found neem to have significant antimicrobial activity against both anaerobic and aerobic bacteria, our findings cannot be directly when compared with those of Ghonmode et al. ${ }^{[7]}$ and Hegde et al..$^{[4]}$ as their study was carried out on Enterococcus faecalis and C. Albicans, which are commonly found in endodontic reinfection cases. Our results are in partial agreement with Dutta et al. ${ }^{[30]}$ who found no difference in antimicrobial efficacy of neem and $2.5 \% \mathrm{NaOCl}$ against anaerobic bacteria. Our findings suggest that there is no difference in the efficacy against facultative, as well as anaerobic bacteria. Our findings also clinically validate those of Mistry et al. ${ }^{[46]}$ who found neem to be very effective against Streptococcus mutans and Staphylococcus aureus in an agar diffusion model.

The ability of MCJ to remove smear layer has been established by Murray et al. ${ }^{[48]}$ and Saghiri et al. ${ }^{[10]}$ However, endodontic literature regarding the antimicrobial efficacy of MCJ is sparse and contradictory with Kandaswamy et al. ${ }^{[49]}$ showing $\mathrm{MCJ}$ to be effective against $E$. faecalis in dentine of extracted teeth. A study by Bhardwaj et al. ${ }^{[50]}$ revealed ultrasonic irrigation of MCJ to be ineffective in completely removing $E$. faecalis biofilm. Our findings showed a significant reduction of CFUs of aerobic, as well as anaerobic bacteria and support the use of MCJ as an endodontic irrigant.

Under the limitations of this study, it was concluded that all the test irrigants caused a significant reduction in the mean CFU counts of aerobic and anaerobic bacteria. Six percentage MCJ and A. indica were as antibacterial as $3 \% \mathrm{NaOCl}$ in root canal irrigation. The null hypothesis was rejected as it was concluded that there was no difference in the antimicrobial efficacy of $6 \% \mathrm{MCJ}, A$. indica, and $3 \% \mathrm{NaOCl}$ as root canal irrigants. Future in vivo studies with combinations of irrigants and the role of ultrasonic activation will best help exploit the maximum efficacy of herbal irrigants.

\section{Financial support and sponsorship \\ Nil.}

\section{Conflicts of interest}

There are no conflicts of interest.

\section{REFERENCES}

1. Siqueira JF Jr, Batista MM, Fraga RC, de Uzeda M. Antibacterial effects of endodontic irrigants on black-pigmented gram-negative anaerobes and facultative bacteria. J Endod 1998;24:414-6.

2. Smiline GA, Pandi SK, Hariprasad P, Raguraman R. A preliminary study on the screening of emerging drug resistance among the caries pathogens isolated from carious dentine. Indian J Dent Res 2012;23:26-30.

3. Poeschl PW, Crepaz V, Russmueller G, Seemann R, Hirschl AM, Ewers R. Endodontic pathogens causing deep neck space infections: Clinical impact of different sampling techniques and antibiotic susceptibility. J Endod 2011;37:1201-5.

4. Regalado Farreras DC, Puente CG, Estrela C. Sodium hypochlorite chemical burn in an endodontist's eye during canal treatment using operating microscope. J Endod 2014;40:1275-9.

5. Al-Sebaei MO, Halabi OA, El-Hakim IE. Sodium hypochlorite accident resulting in life-threatening airway obstruction during root canal treatment: A case report. Clin Cosmet Investig Dent 2015;7:41-4.

6. Ok E, Adanir N, Hakki S. Comparison of cytotoxicity of various concentrations origanum extract solution with $2 \%$ chlorhexidine gluconate and 5.25\% sodium hypochlorite. Eur J Dent 2015;9:6-10.

7. Ghonmode WN, Balsaraf OD, Tambe VH, Saujanya KP, Patil AK, Kakde DD. Comparison of the antibacterial efficiency of neem leaf extracts, grape seed extracts and 3\% sodium hypochlorite against E. feacalis - An in vitro study. J Int Oral Health 2013;5:61-6.

8. Pujar M, Makandar S. Herbal usage in endodontics - A review. Int J Contemp Dent 2011;2:34-7.

9. Oncag O, Cogulu D, Uzel A, Sorkun K. Efficacy of propolis as an intracanal medicament against Enterococcus faecalis. Gen Dent 2006;54:319-22

10. Saghiri MA, Garcia-Godoy F, Asgar K, Lofti M. The effect of Morinda citrifolia juice as an endodontic irrigant on smear layer and microhardness of root canal dentin. Oral Sci Int 2013;10:53-7.

11. Wang MY, West BJ, Jensen CJ, Nowicki D, Su C, Palu AK, et al. Morinda citrifolia (Noni): A literature review and recent advances in Noni research. Acta Pharmacol Sin 2002;23:1127-41.

12. Younos C, Rolland A, Fleurentin J, Lanhers MC, Misslin R, Mortier F. Analgesic and behavioural effects of Morinda citrifolia. Planta Med 1990;56:430-4.

13. Li RW, Myers SP, Leach DN, Lin GD, Leach G. A cross-cultural study: Anti-inflammatory activity of Australian and Chinese plants. J Ethnopharmacol 2003;85:25-32.

14. Jain A, Basal E. Inhibition of Propionibacterium acnes-induced mediators of inflammation by Indian herbs. Phytomedicine 2003;10:34-8.

15. Okpanyi SN, Ezeukwu GC. Anti-inflammatory and antipyretic activities of Azadirachta indica. Planta Med 1981;41:34-9.

16. Upadhyay SN, Dhawan S, Garg S, Talwar GP. Immunomodulatory effects of neem (Azadirachta indica) oil. Int J Immunopharmacol 1992;14:1187-93.

17. Pai MR, Acharya LD, Udupa N. Evaluation of antiplaque activity of Azadirachta indica leaf extract gel - A 6-week clinical study. J Ethnopharmacol 2004;90:99-103.

18. Fabry W, Okemo PO, Ansorg R. Antibacterial activity of East African medicinal plants. J Ethnopharmacol 1998;60:79-84.

19. Natarajan V, Pushkala S, Karuppiah VP, Prasad PV. Anti dermatophytic activity of Azardirachta indica (neem) by in vitro study. Indian J Pathol Microbiol 2002;45:311-3.

20. Nwosu MO, Okafor JI. Preliminary studies of the antifungal activities 
of some medicinal plants against Basidiobolus and some other pathogenic fungi. Mycoses 1995;38:191-5.

21. Subapriya R, Nagini S. Medicinal properties of neem leaves: A review. Curr Med Chem Anticancer Agents 2005;5:149-6.

22. Möller AJ. Microbiological examination of root canals and periapical tissues of human teeth. Methodological studies. Odontol Tidskr 1966;74 Suppl: 1-380.

23. Tsatsas B, Tzamouranis A, Mitsis F. A bacteriological examination of root canals before filling. J Br Endod Soc 1974;7:78-80.

24. Yoneda M, Kita S, Suzuki N, Macedo SM, Iha K, Hirofuji T. Application of a chairside anaerobic culture test for endodontic treatment. Int J Dent 2010;2010:942130.

25. West BJ, Jensen CJ, Westendorf J. Noni juice is not hepatotoxic. World J Gastroenterol 2006;12:3616-9.

26. West BJ, Su CX, Jensen CJ. Hepatotoxicity and subchronic toxicity tests of Morinda citrifolia (Noni) fruit. J Toxicol Sci 2009;34:581-5.

27. Murata K, Abe Y, Futamura-Masudaa M, Uwaya A, Isami F, Matsuda H. Activation of cell-mediated immunity by Morinda citrifolia fruit extract and its constituents. Nat Prod Commun 2014;9:445-50.

28. Sattar FA, Ahmed F, Ahmed N, Sattar SA, Malghani MA, Choudhary MI. A double-blind, randomized, clinical trial on the antileishmanial activity of a Morinda citrifolia (Noni) stem extract and its major constituents. Nat Prod Commun 2012;7:195-6.

29. Thakurta P, Bhowmik P, Mukherjee S, Hajra TK, Patra A, Bag PK. Antibacterial, antisecretory and antihemorrhagic activity of Azadirachta indica used to treat cholera and diarrhea in India. J Ethnopharmacol 2007;111:607-12.

30. Dutta A, Kundabala M. Comparative anti-microbial efficacy of Azadirachta indica irrigant with standard endodontic irrigants: A preliminary study. J Conserv Dent 2014;17:133-7.

31. Wang C, Cao M, Shi DX, Yin ZQ, Jia RY, Wang KY, et al. A 90-day subchronic toxicity study of neem oil, a Azadirachta indica oil, in mice. Hum Exp Toxicol 2013;32:904-13.

32. Deng YX, Cao M, Shi DX, Yin ZQ, Jia RY, Xu J, et al. Toxicological evaluation of neem (Azadirachta indica) oil: Acute and subacute toxicity. Environ Toxicol Pharmacol 2013;35:240-6.

33. Mallick A, Ghosh S, Banerjee S, Majumder S, Das A, Mondal B, et al. Neem leaf glycoprotein is nontoxic to physiological functions of Swiss mice and Sprague Dawley rats: Histological, biochemical and immunological perspectives. Int Immunopharmacol 2013;15:73-83.

34. Dorababu M, Joshi MC, Bhawani G, Kumar MM, Chaturvedi A, Goel RK. Effect of aqueous extract of neem (Azadirachta indica) leaves on offensive and diffensive gastric mucosal factors in rats. Indian J Physiol Pharmacol 2006;50:241-9.

35. Bandyopadhyay U, Biswas K, Sengupta A, Moitra P, Dutta P, Sarkar D, et al. Clinical studies on the effect of Neem (Azadirachta indica) bark extract on gastric secretion and gastroduodenal ulcer. Life Sci 2004;75:2867-78.

36. Smith CS, Setchell DJ, Harty FJ. Factors influencing the success of conventional root canal therapy - A five-year retrospective study. Int Endod J 1993;26:321-33.

37. Ng YL, Spratt D, Sriskantharajah S, Gulabivala K. Evaluation of protocols for field decontamination before bacterial sampling of root canals for contemporary microbiology techniques. J Endod 2003;29:317-20.

38. Brugger SD, Baumberger C, Jost M, Jenni W, Brugger U, Mühlemann K. Automated counting of bacterial colony forming units on agar plates. PLoS One 2012;7:e33695.

39. Seal GJ, Ng YL, Spratt D, Bhatti M, Gulabivala K. An in vitro comparison of the bactericidal efficacy of lethal photosensitization or sodium hyphochlorite irrigation on Streptococcus intermedius biofilms in root canals. Int Endod J 2002;35:268-74

40. Zhu X, Yin X, Chang JW, Wang Y, Cheung GS, Zhang C. Comparison of the antibacterial effect and smear layer removal using photon-initiated photoacoustic streaming aided irrigation versus a conventional irrigation in single-rooted canals: An in vitro study. Photomed Laser Surg 2013;31:371-7.

41. Tennert C, Drews AM, Walther V, Altenburger MJ, Karygianni L, Wrbas KT, et al. Ultrasonic activation and chemical modification of photosensitizers enhances the effects of photodynamic therapy against Enterococcus faecalis root-canal isolates. Photodiagnosis Photodyn 2015;12:244-51.

42. Malkhassian G, Manzur AJ, Legner M, Fillery ED, Manek S, Basrani BR, et al. Antibacterial efficacy of MTAD final rinse and two percent chlorhexidine gel medication in teeth with apical periodontitis: A randomized double-blinded clinical trial. J Endod 2009;35:1483-90.

43. Siqueira JF Jr, Rôças IN, Santos SR, Lima KC, Magalhães FA, de Uzeda M. Efficacy of instrumentation techniques and irrigation regimens in reducing the bacterial population within root canals. J Endod 2002;28:181-4.

44. Tyagi SP, Sinha DJ, Garg P, Singh UP, Mishra CC, Nagpal R. Comparison of antimicrobial efficacy of propolis, Morinda citrifolia, Azadirachta indica (Neem) and 5\% sodium hypochlorite on Candida albicans biofilm formed on tooth substrate: An in-vitro study. J Conserv Dent 2013;16:532-5.

45. Hegde V, Kesaria DP. Comparative evaluation of antimicrobial activity of neem, propolis, turmeric, liquorice and sodium hypochlorite as root canal irrigants against $E$. fecalis and C. albicans - An in vitro study. Endodontology 2013;25:38-45.

46. Mistry KS, Sanghvi Z, Parmar G, Shah S. The antimicrobial activity of Azadirachta indica, Mimusops elengi, Tinospora cardifolia, Ocimum sanctum and $2 \%$ chlorhexidine gluconate on common endodontic pathogens: An in vitro study. Eur J Dent 2014;8:172-7.

47. Vinothkumar TS, Rubin MI, Balaji L, Kandaswamy D. In vitro evaluation of five different herbal extracts as an antimicrobial endodontic irrigant using real time quantitative polymerase chain reaction. J Conserv Dent 2013;16:167-70.

48. Murray PE, Farber RM, Namerow KN, Kuttler S, Garcia-Godoy F Evaluation of Morinda citrifolia as an endodontic irrigant. J Endod 2008;34:66-70.

49. Kandaswamy D, Venkateshbabu N, Gogulnath D, Kindo AJ. Dentinal tubule disinfection with $2 \%$ chlorhexidine gel, propolis, Morinda citrifolia juice, $2 \%$ povidone iodine, and calcium hydroxide. Int Endod J 2010;43:419-23.

50. Bhardwaj A, Velmurugan N, Sumitha, Ballal S. Efficacy of passive ultrasonic irrigation with natural irrigants (Morinda citrifolia juice, Aloe vera and propolis) in comparison with $1 \%$ sodium hypochlorite for removal of E. faecalis biofilm: An in vitro study. Indian J Dent Res 2013;24:35-41.

\begin{tabular}{|l|l|}
\hline \multicolumn{2}{|c|}{ Access this article online } \\
\hline Quick Response Code: & \\
\hline
\end{tabular}

